\title{
Digital transformation of the customer interaction system in the business model of the organization based on the omnichannel approach
}

\author{
Evgeniya Nigay", Yuliya Lebedinskaya, and Elena Koshevaya \\ Vladivostok State University of Economics and Service, Vladivostok, Russia
}

\begin{abstract}
Maintaining a competitive position in the market in the context of digitalization becomes difficult or impossible without creating new sources of competitive advantage. The digitalization of the economy and business requires a corresponding change in the business model of the organization. One of the most urgent areas of enhancement in the structure of the business model is the system of interaction with the client. Its timely transformation provides an integrated system approach to service and customer interaction based on an omnichannel approach using a balanced and multifunctional system of digital and traditional communication channels. The article proposes the author's approach to transforming the system of interaction with a client (through the "omnichannel prism") in the context of the digitalization of the economy and business, defines the requirements for a business model and developed a system of indicators for assessing its efficiency.
\end{abstract}

\section{Introduction}

The formation and retention of stable competitive positions in the market in the context of digitalization is largely due to the ability of businesses to find and use new sources of competitive advantages. Robotization and automation, cloud technologies, digital channels of interaction with customers and partners open up opportunities for the implementation of innovative ways of enterprise development. The development of digital technologies provokes serious transformations of both individual business processes of an organization and business models in general.

The use of strategies for the digital transformation of business models involves the combination of physical business assets with digital ones and today is an irrefutable condition for the successful functioning and development of organizations.

An innovative business model that meets the conditions of digitalization should meet a number of technological, structural, managerial and economic requirements. A brief overview of existing approaches to formulating the necessary characteristics of the business model of an organization in the digital era is presented in Table 1.

\footnotetext{
*Corresponding author: jenia_nigay@mail.ru
} 
Table 1. Overview of concepts and requirements for an innovative business model of an organization.

\begin{tabular}{|c|c|c|}
\hline Prepared by & Concept & Requirements for an innovative business model \\
\hline $\begin{array}{c}\text { O. Gassman } \\
{[1]}\end{array}$ & Magic triangle concept & $\begin{array}{l}\text { The business model should define: } \\
\text { 1. Who are your customers. } \\
\text { 2. What do you sell. } \\
\text { 3. How you form an offer and why your business is } \\
\text { profitable. } \\
\text { The who - what - how and why approach describes a } \\
\text { business model in which the first two components } \\
\text { (who and what) relate to external aspects, and the third } \\
\text { (how and why) to internal dimensions [1]. }\end{array}$ \\
\hline $\begin{array}{c}\text { A. } \\
\text { Osterwald } \\
\text { and I. } \\
\text { Pignet [2] }\end{array}$ & $\begin{array}{l}\text { Building business } \\
\text { models pursuant to the } \\
\text { author's template and } \\
\text { pursuant to "consumer } \\
\text { tips" }\end{array}$ & $\begin{array}{l}\text { 1. The ability to meet the needs of the market. } \\
\text { 2. Adaptability pursuant to the market reaction to it. } \\
\text { 3. Controllability [2]. }\end{array}$ \\
\hline $\begin{array}{l}\text { K. Linz, } \\
\text { G. Müller- } \\
\text { Stevens, A. } \\
\text { Zimmerma } \\
\quad \text { nn [4] }\end{array}$ & $\begin{array}{l}\text { The transformation is } \\
\text { based on two } \\
\text { megatrends: } \\
\text { digitalization and service } \\
\text { orientation ("service") }\end{array}$ & $\begin{array}{l}\text { A successful radical transformation requires change in } \\
\text { three areas: } \\
\text { 1. Working with clients. } \\
\text { 2. Support services. } \\
\text { 3. Monetization mechanisms [4]. }\end{array}$ \\
\hline $\begin{array}{l}\text { Microsoft } \\
\text { analysts [5] }\end{array}$ & $\begin{array}{l}\text { The concept of a } \\
\text { comprehensive } \\
\text { transformation, which } \\
\text { includes not only the } \\
\text { process of replacing } \\
\text { technologies, but also a } \\
\text { change in corporate } \\
\text { culture and corporate } \\
\text { practices }\end{array}$ & $\begin{array}{l}\text { 1. Radical efficiency gains: the organization's key } \\
\text { performance indicators should enhance dramatically. } \\
\text { 2. Leveraging modern technologies that are } \\
\text { economical, scalable and flexible. } \\
\text { 3. The presence of cross-cutting changes, i.e. the } \\
\text { project should affect several areas of the business [5]. }\end{array}$ \\
\hline $\begin{array}{l}\text { A. Prokhorov, } \\
\text { L. Konik [6] }\end{array}$ & $\begin{array}{l}\text { Digital Competitiveness } \\
\text { Index }\end{array}$ & $\begin{array}{l}\text { 1. Adaptability. } \\
\text { 2. Flexibility. } \\
\text { 3. IT integration. } \\
\text { 4. Technological environment. } \\
\text { 5. Capital. } \\
\text { 6. Human resources [6]. }\end{array}$ \\
\hline $\begin{array}{c}\text { Kitova O.V., } \\
\text { Bruskin S.N. } \\
\quad[7]\end{array}$ & $\begin{array}{l}\text { Development of digital } \\
\text { models of corporate } \\
\text { governance for } \\
\text { each company assumes } \\
\text { systematic work to select } \\
\text { the } \\
\text { priority digital circuits in } \\
\text { the organization's } \\
\text { information system }\end{array}$ & $\begin{array}{l}\text { 1. Digital development strategy. } \\
\text { 2. Digital management of operational efficiency. } \\
\text { 3. Digital transformation of the organizational } \\
\text { structure. } \\
\text { 4. Digital transformation of business processes. } \\
\text { 5. Information and analytical support of digital control. } \\
\text { 6. Decision-making speed (real-time models in RTS) } \\
\text { [7]. } \\
\text { 7. Working with digital data (integration of Advanced } \\
\text { analytics with the digital processes of the corporation). } \\
\text { 8. Digital competencies of personnel. }\end{array}$ \\
\hline
\end{tabular}

Within the framework of the proposed approach, the following requirements are formulated for the business model of an organization in the context of digitalization [8]:

1. Technological equipment. The availability of modern digital tools for doing business and communication with the external environment is one of the main management tools for digitalization. 
2. Adaptability and compliance with market changes. One of the main requirements for the IT ecosystem of a digital company is to ensure flexibility and quick response to market demands.

3. Controllability. The management phase includes continuous model assessment and environment scanning.

4. Economic efficiency. A business model is a tool used by a company to make a profit.

5. Targeted market orientation. The business model should meet market requirements and have a target orientation to meet the needs and demands of target customer segments.

6. Provision of staff with digital competencies. It is important to pay attention to the issues of improving the training of personnel with the involvement of the capabilities of industry companies.

7. Focus on interaction, customer experience and content.

The implementation of these conditions will allow the company to succeed in the problematic field of digital transformation of its business model.

The given set of requirements makes it possible to determine the criteria for an efficient business model created in the context of digitalization, and to ensure the possibility of its application in practice [9].

\section{Methods}

The digitalization of the economy and business inevitably leads to the transformation of business processes and business models. The proposed author's approach involves the implementation of the following sequence of stages of transformation of the organization's business model in the context of digitalization: determining the requirements for the business model - choosing tools - modeling - evaluating efficiency.

The theoretical and methodological basis of the study was formed by the main provisions of the functioning and development of economic systems and entrepreneurial structures, the problems of legal regulation of digital processes, as well as methods of business modeling in the context of digitalization.

As a toolkit and research methods, a systematic, integrated approach to studying the transformation of a business model in the digital economy, structured content analysis to formulate requirements for business models, business modeling and graphical techniques were used.

\section{Results}

Changes in the external environment of the organization force the latter to continuously respond to them, through a complete transformation of the organization's business model or its partial enhancement. The proposed approach to the transformation of the organization's business model is based primarily on the transformation as a result of digitalization of the system of interaction with the client. This is the frontal part of the organization's business model, which requires priority adaptation to changes in the external environment and the market, as it characterizes the activity and flexibility of the business in meeting customer needs. The focus of change is focused on the growth strategy by better understanding the customer and increasing points of contact with him.

Figure 1 shows the structure of the organization's business model and its transformation in the segment of customer interaction as a result of digitalization based on the omnichannel approach [10]. 


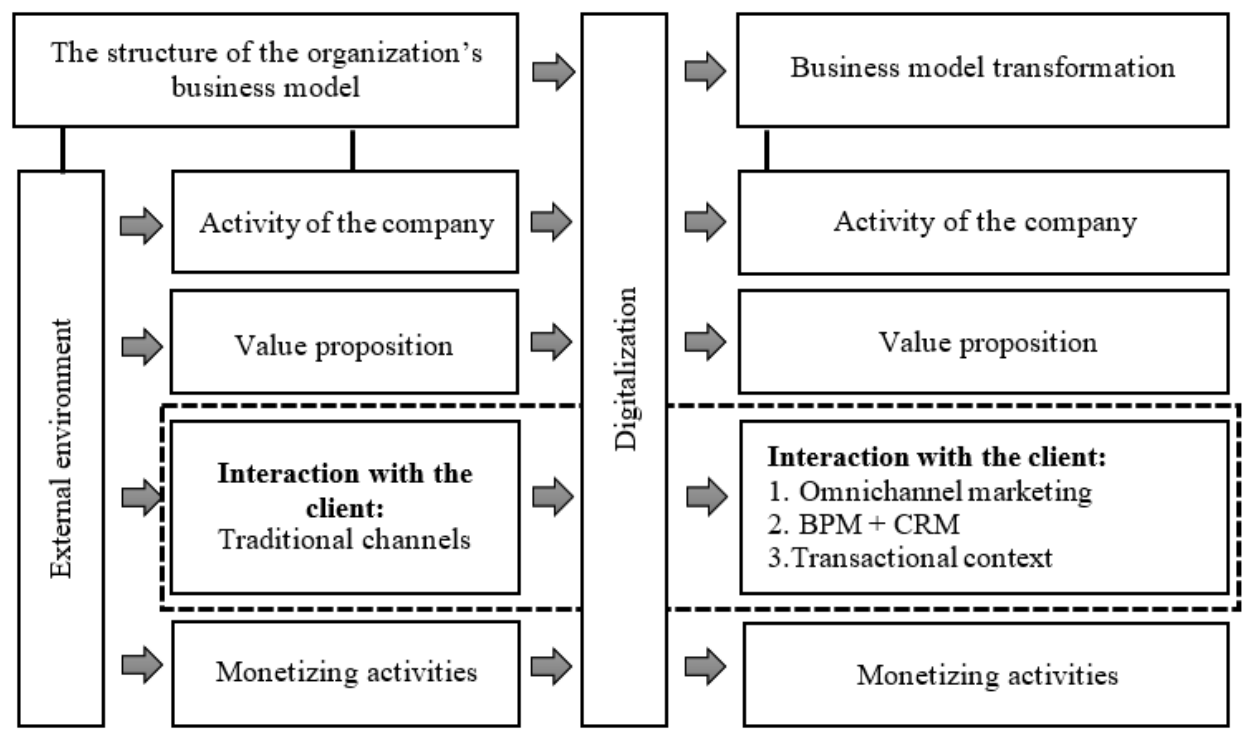

Fig. 1. Transformation of the system of interaction with the client in the context of the digitalization of the market based on the omnichannel approach.

The proposed approach is developed on the basis of a combination of the digital business model "Omnichannel" (P. Vaila, S. Warner) [3] and the template of the business model of A. Osterwalder and I. Pignet [2] in terms of considering the system of interaction with the client.

In general, the company's business model can be represented in the form of four structural sectors:

1) company activities - key partners, key resources, activities;

2) value proposition - what is the value of the company in the consumer's eyes in the market;

3) customer interaction - consumer segments, customer relationships, sales channels;

4) monetization of activities - the structure of costs, income streams.

The transformations in the Customer Experience sector are disclosed in detail through the Omnichannel prism or omnichannel approach.

The omnichannel approach assumes the integrated interaction of the company with the client, through the use of a single coordinated system of channels, thanks to which the impression of continuous communication is created [10].

When comparing the use of traditional channels and multichannel approach in the predigital era with the modern innovative omnichannel approach, it is necessary to emphasize the following. The multichannel approach addresses the consumer through as many channels as possible, the main task of which is to ensure maximum reach, frequency and customer engagement on a "more is better" basis. The omnichannel approach, in addition to significantly expanding the range of digital interaction tools used, ties together each channel with a single accounting system, interacting with customers in a complex, simultaneously across all channels and individually for each channel separately.

The specification of the omnichannel approach found expression in the "Omnichannel prism" proposed by the authors, the structure of which is shown in Figure 2. Its content characterizes the construction of an efficient system of interaction with the client in the context of the digitalization of the economy, business and the organization of service activities. 


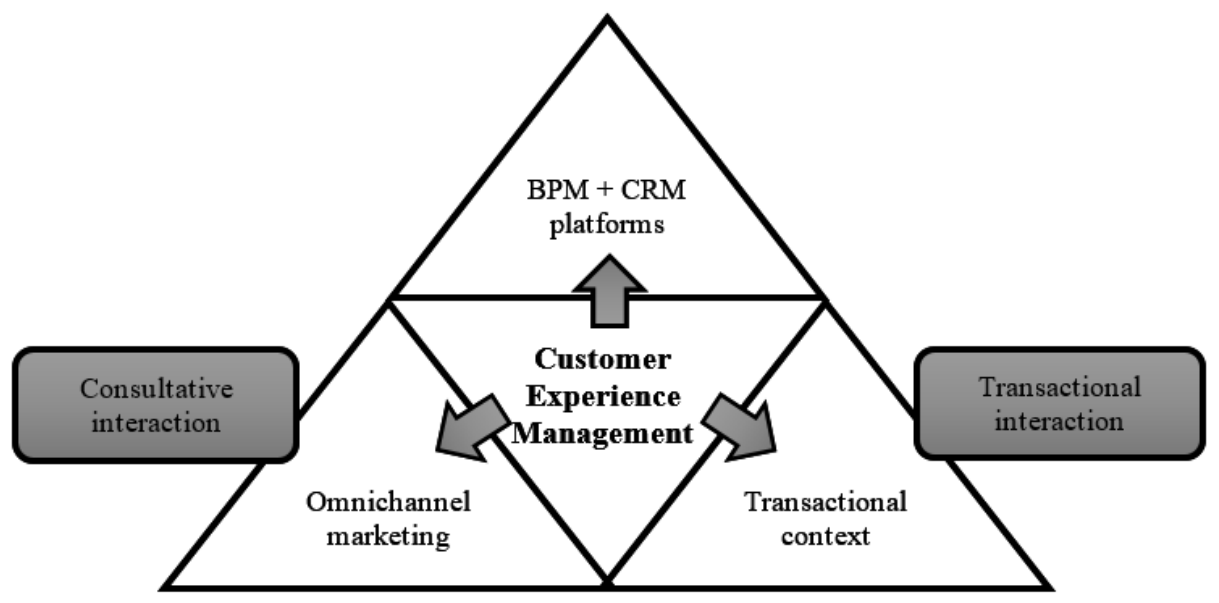

Fig. 2. Omnichannel prism.

The developed model of the omnichannel prism includes three main elements.

1. Omnichannel marketing. In general, it assumes a digital integrated approach to customer experience management based on the involvement of an agreed set of communication tools: content marketing, messenger marketing, SMM marketing, email marketing etc.

2. Unified platform BPM (Business Process Management) + CRM (Customer Relationship Management). A single platform (as a digital service) in the presence of a CRM system allows to "switch" a client from one channel to another, (using the CRM system database) without breaking the logic of the client's interaction with the company, with the subsequent development of a development strategy, modeling and performance evaluation for each business -process.

3. Transactional context. When introducing and using digital customer engagement tools in an omnichannel approach, one cannot focus on digital engagement alone. It is necessary to remember about the client's route, which he takes from meeting with companies in the digital space to the possible conclusion of a transaction offline.

All three components are necessary for customer experience management, which is aimed at comprehensive, systematic support of the client at all stages of the interaction process, from making a decision to purchasing goods and services, both through digital and offline channels. As a result, interaction with the client is built in two directions:

1) consultative interaction;

2) transactional interaction.

Consultative interaction directly depends on omnichannel marketing, transactional interaction with the client occurs due to the development of the transactional context building a clear vision of the "client's route" (which way he can go from digital online channels to traditional ones). In the process of digitalization, it is necessary to consider the "real" stage of interaction with the client, while maintaining efficient interaction with the client across all channels.

\section{Discussion of the results}

It is proposed to evaluate the efficiency of the proposed transformed business model based on the system of indicators presented in Figure 3. 


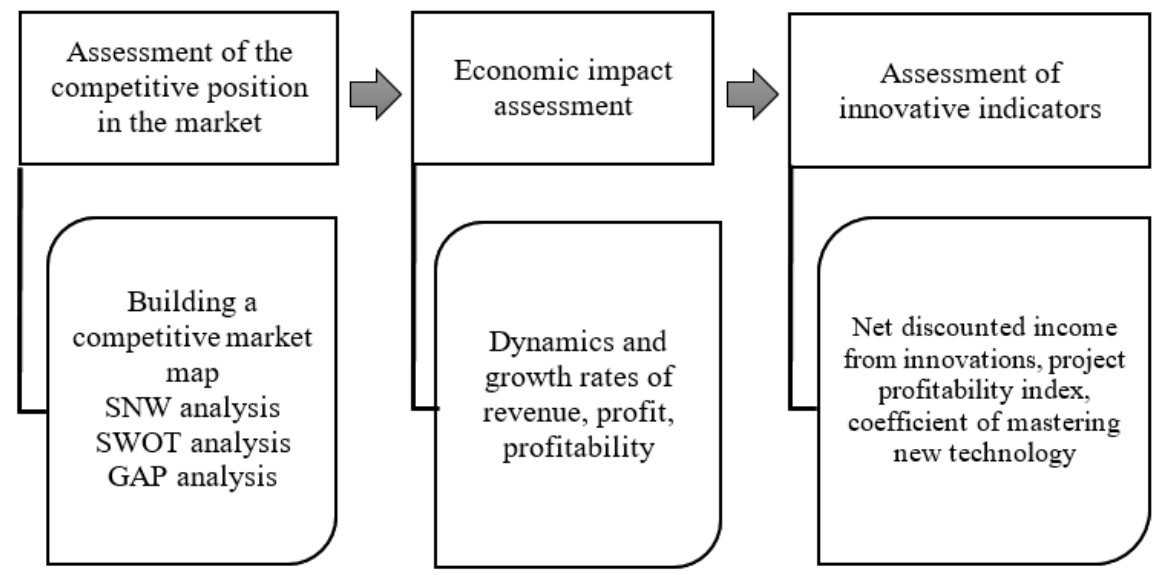

Fig. 3: A comprehensive system of indicators for assessing the efficiency of a business model.

The complex for assessing the consequences of digital business transformation is formulated on the basis of three assessment modules: expected competitive advantages, expected direct economic effects, and innovativeness criteria.

The first block of performance indicators of the model is the determination of the company's competitive status (competitiveness). Its assessment allows to determine the change in the competitive position of the enterprise as a result of the transformation of the business model based on digitalization and an omnichannel approach. Analysis in this direction involves the sequential implementation of measurements and comparative assessment of the position "before" and "after" events.

The second block of performance indicators of the model is the determination of the expected general economic effects of an innovative business model. To assess the economic efficiency of the transformation of the business model, general economic indicators are used: revenue, net profit, profitability.

The indicators of the innovation block imply an assessment of the efficiency of the omnichannel approach and the transformed business model in the organization as a result of the development of digital channels of customer interaction and technologies. The number of mastered, implemented digital technologies and communication channels characterize the digital activity of the company. The indicators of the personnel employed in $R \& D$, the development of new technology, as well as the net discounted income from innovations and the profitability of the project are assessed.

\section{Conclusions}

The proposed theoretical and methodological approach to transforming the business model of an organization in the context of digitalization and assessing the consequences of digital transformation involves improving the system of interaction with a client based on an omnichannel approach and a complex combination of digital and traditional channels of interaction. The formulated requirements for the business model ensure the formation of a system of criteria for efficient business transformation in modern market conditions. It is proposed to assess the consequences of the transformation based on the determination of the company's competitive position by the methods of competitive analysis; assessing the economic effect, as well as assessing innovative indicators. 


\section{References}

1. K. Frankenberger, M. Chick, Business Models: The 55 Best Templates (2017)

2. I. Pin'ye, Postroyeniye biznes-modeley. Nastol'naya kniga stratega i novatora (2010)

3. P. Wile, S. Warner, Digital Business Transformation. Changing the Business Model for a Next Generation Organization (2019)

4. K. Linz, G. Müller-Stevens, A. Zimmerman, Business Change: Adapting and Surviving in a Competitive Environment (2019)

5. Microsoft "A Guide to the Future How Multi-Industry Companies in Central and Eastern Europe Operate in the Digital Revolution" (2018 report). https://www.microsoft.com

6. A. Prokhorov, L. Konik, Tsifrovaya transformatsiya. Analiz, trendy, mirovoy opyt (2019)

7. O.V. Kitova, S.N. Bruskin, Tsifrovaya ekonomika. 2017. http://digitaleconomy.ru/stati/tsifrovaya-transformatsiya-biznesa

8. Y. S. Lebedinskaya, E. A. Nigay, Int. J. of Supply Chain Management, 8(6) (2019).

9. Ye.A. Nigay, I.V. Popova, Azimut nauchnykh issledovaniy: ekonomika i upravleniye 2 (27) (2019)

10. R. S. Blizkiy, V. E. Malinenko, Y. S. Lebedinskaya, Socio-economic Systems: Paradigms for the Future, Studies in Systems, Decision and Control 314, 521 (2021) 